\title{
PELAKSANAAN PEMBELAJARAN JARAK JAUH (PJJ) DI TENGAH PANDEMI COVID- 19 PADA MATA PELAJARAN BIOLOGI KELAS X SMA NEGERI 2 MEDAN TP. 2020/2021
}

\author{
Jimmy Francius Simbolon \\ STKIP Riama Medan, Indonesia. \\ Email: kevkez2015@gmail.com.
}

\begin{abstract}
This research is a descriptive study which aims to obtain an overview of the implementation of distance learning (PJJ) in the middle of the Covid-19 pandemic in biology subject in Class X SMA Negeri 2 Medan TP. 2020/2021. The research subjects were students of class X. The research instruments were interviews with the teacher and giving questionnaires to students. The results showed that: Teachers and students of Class X SMA Negeri 2 Medan TP. 2020/2021 has implemented Distance Learning (PJJ). Students carry out PJJ every day, an average of 5-6 hours per day. Students take online classes provided by the teacher, namely Google Classroom, interact via video conference (zoom cloud meeting), Instagram, group chat (telegram, whatsapp), as well as through other online learning applications. Students think they can still understand the learning material, it's fun, it's easy to get learning resources, and can still concentrate. However, some students complained that they could not ask directly to the teacher or friends, and were bored.
\end{abstract}

Keywords: Distance learning (PJJ), Covid-19, Biology

\begin{abstract}
ABSTRAK
Penelitian ini merupakan penelitian deskriptif yang bertujuan untuk memperoleh gambaran tentang pelaksanaan pembelajaran jarak jauh (PJJ) di tengah pandemi Covid-19 pada mata pelajaran Biologi di kelas X SMA Negeri 2 Medan TP. 2020/2021. Subjek penelitian adalah siswa kelas X. Instrumen penelitian berupa wawancara dengan guru dan pemberian angket kepada siswa. Hasil penelitian menunjukkan bahwa: Guru dan siswa kelas X SMA Negeri 2 Medan TP. 2020/2021 telah menerapkan Pembelajaran Jarak Jauh (PJJ). Mahasiswa melaksanakan PJJ setiap hari, rata-rata 5-6 jam perhari. Siswa mengikuti kelas online yang disediakan oleh guru yaitu Google Classroom, berinteraksi melalui video conference (zoom cloud meeting), Instagram, group chat (telegram, whatsapp), serta melalui aplikasi pembelajaran online lainnya. Siswa merasa masih bisa memahami materi pembelajaran, menyenangkan, mudah mendapatkan sumber belajar, dan tetap bisa konsentrasi. Namun, beberapa siswa mengeluh tidak bisa bertanya langsung kepada guru atau teman, dan merasa bosan.
\end{abstract}

Kata Kunci : Pembelajaran Jarak Jauh (PJJ), Covid-19, Biologi

\section{PENDAHULUAN}

Coronavirus Disease 19 atau Covid-19 pertama kali muncul di Wuhan, Tiongkok, pada Desember 2019. Penyebabnya adalah virus corona jenis baru yang disebut SARS Cov-2. Virus ini menyerang saluran pernapasan dan menyebabkan penyakit infeksi saluran pernapasan. Dalam tempo yang tergolong singkat, virus ini menyebar ke berbagai daerah lainnya di Tiongkok, kemudian ke negara-negara lain. Setelah hampir 2 bulan menjadi wabah, Organisasi Kesehatan Dunia (WHO) pada 30 Januari 2020 pun menyatakan darurat global terhadap virus corona. Di Indonesia, kasus pertama Covid-19 terkonfirmasi pada 2 Maret 2020. Hanya dalam tempo 8 hari, yakni pada tanggal 10 April 2020, penyebarannya telah meluas di 34 provinsi di Indonesia. (cnn indonesia, 2020).

Meskipun data menunjukkan beberapa kelompok tertentu misalnya kelompok muda memiliki daya tahan tubuh yang lebih baik dibanding kelompok lansia dan penderita penyakit kronis, namun bukan berarti kelompok muda tidak mungkin terkena. Bisa saja kelompok muda sudah terinfeksi namun tidak menunjukkan gejala seperti demam $>38^{\circ} \mathrm{C}$, batuk dan sesak nafas (Siagian, 2020). 
Sebagai usaha pencegahan penyebaran Covid-19, WHO merekomendasikan untuk menghentikan sementara kegiatan-kegiatan yang berpotensi menimbulkan kerumunan massa. Pemerintah melakukan banyak cara untuk mencegah penularan Covid-19. Menteri Pendidikan dan Kebudayaan (Mendikbud) Nadiem Anwar Makarim menerbitkan Surat Edaran Nomor 4 Tahun 2020 tentang Pelaksanaan Pendidikan Dalam Masa Darurat Coronavirus Disease (Covid-19). Salah satu pokok penting dalam edaran ini adalah keputusan pembatalan ujian nasional (UN) Tahun 2020. Menteri juga memutuskan untuk tidak memperbolehkan Ujian Sekolah dan Ujian Akhir Semester tatap muka serta melaksanakan belajar dari rumah melalui pembelajaran daring/ jarak jauh dan fokus pendidikan pada kecakapan hidup antara lain mengenai pandemi Covid19. (Kemdikbud, 2020). Selanjutnya, pemerintah juga menerbitkan Peraturan Menteri Pendidikan dan Kebudayaan RI Nomor 19 Tahun 2020 yang antara lain mengatur tentang penggunaan dana Bantuan Operasional Sekolah (BOS) untuk pembelian pulsa, paket data dan/atau layanan pendidikan daring berbayar bagi pendidik dan/atau peserta didik (Ariadhy, 2020).

Indonesia telah menutup semua sekolah sejak awal bulan Maret sehingga 60 juta siswa tidak dapat bersekolah. (Muhammadiyah \& Utara, 2020), Undang-undang No. 14 Tahun 2005 tentang Guru dan Dosen mengemukakan kompetensi pedagogik adalah 'kemampuan mengelola pembelajaran peserta didik'. Sekolah-sekolah diminta memfasilitasi pembelajaran dari rumah menggunakan sejumlah platform digital milik pemerintah dan swasta yang memberikan konten secara gratis dan peluang pembelajaran daring dan dari jarak jauh di seluruh daerah. Penutupan sekolah di Indonesia sejak bulan Maret 2020 dan dimulainya pembelajaran daring telah menimbulkan sejumlah permasalahan seperti kesenjangan akses terhadap pendidikan yang berkualitas, kesulitan orang tua dalam mendampingi proses belajar daring dan ketidakmerataan literasi digital siswa (Unicef, 2020).

Wabah corona virus disease 2019 (Covid-19) yang telah melanda 215 negara di dunia, memberikan tantangan tersendiri bagi lembaga pendidikan (Sadikin, 2020). Para guru mengalami sejumlah kendala dalam melaksanakan pembelajaran jarak jauh. Pada tahap awal terjadinya penyebaran Covid-19, para guru dinilai tidak siap dalam menentukan instrumen pembelajaran secara cepat dan tepat sebagai pengganti dari pertemuan tatap muka. Tingginya kebutuhan kuota internet dalam pembelajaran jarak jauh menjadi hambatan lain bagi para guru maupun siswa. Selain itu, tidak semua wilayah memiliki kualitas jaringan internet yang baik. Guru harus mampu menemukan metode pembelajaran dan menetapkan sistem penilaian yang objektif agar kompetensi dasar yang diinginkan dari sebuah mata pelajaran dapat dicapai melalui pembelajaran jarak jauh (Rigianti, 2020).

Untuk mengetahui pelaksanaan pembelajaran jarak jauh (PJJ) di tengah pandemi Covid-19, maka peneliti menganggap perlu melakukan penelitian tentang Pelaksanaan Pembelajaran Jarak Jauh (PJJ) di Tengah Pandemi Covid- 19 Pada Mata Pelajaran Biologi Kelas X SMA Negeri 2 Medan TP. 2020/2021

\section{METODE PENELITIAN}

\section{Lokasi dan Waktu Penelitian}

Penelitian dilaksanakan di SMA Negeri 2 Medan melalui media komunikasi Whatsapp dan zoom cloud meeting. Waktu penelitian adalah pada September-Oktober 2020.

\section{Populasi dan Sampel}

Yang menjadi populasi pada penelitian adalah Guru Biologi dan Siswa kelas SMA Negeri 2 Medan. Sampel penelitian adalah siswa kelas X MIPA 1, X MIPA 2, X MIPA 5, X MIPA 6 dan X MIPA 7 yang berjumlah 180 orang. 
Sampling dalam penelitian ini memakai teknik purposive sampling. Dari teknik sampling ini diambil sebanyak 25\% dari total sampel yaitu 45 orang (Arikunto, 2013).

\section{Jenis Penelitian}

Penelitian ini merupakan penelitian deskriptif yang bertujuan untuk memperoleh gambaran pembelajaran jarak jauh yang dilaksanakan di SMA Negeri 2 Medan sebagai usaha untuk menekan penyebaran Covid-19 di lingkungan sekolah. Pembelajaran jarak jauh yang dimaksud dalam penelitian ini adalah pembelajaran yang menggunakan media internet. Penelitian deskriptif berfungsi untuk mendeskripsikan atau memberi gambaran terhadap obyek yang diteliti melalui data atau sampel yang telah terkumpul sebagaimana adanya, tanpa melakukan analisis dan membuat kesimpulan yang umum (Sugiyono, 2011).

\section{Data dan Sumber Data}

a) Data

Jenis data yang digunakan dalam penelitian ini adalah data kuantitatif berupa jumlah siswa dan hasil angket. Data kuantitatif adalah jenis data yang dapat diukur atau dihitung secara langsung, yang berupa informasi atau penjelasan yang dinyatakan dengan bilangan atau berbentuk angka (Sugiyono, 2011).

b) Sumber Data

Penelitian ini menggunakan satu sumber data primer yang dikumpulkan oleh peneliti dari sumber pertama yaitu siswa kelas X MIPA 1, X MIPA 2, X MIPA 5, X MIPA 6 dan X MIPA 7 pada mata pelajaran Biologi.

Teknik Pengumpulan Data

Pengumpulan data dilakukan melalui angket dan pengamatan melalui zoom cloud meeting. Aspek-aspek yang ditanyakan dalam angket adalah: Pelaksanaan PJJ, interaksi dengan guru, aplikasi yang digunakan, hambatan dan dukungan dari sekolah selama PJJ. Analisis data penelitian dilakukan menggunakan model analisis Miles \& Huberman yang terdiri dari tiga tahapan, yaitu reduksi data, display data, serta penarikan dan verifikasi kesimpulan.

Analisis data penelitian tahap reduksi data merupakan tahap mengumpulkan seluruh informasi yang dibutuhkan dari hasil angket lalu di kelompokkan datanya. Tahap display data merupakan pemaparan data yang diperlukan dalam penelitian dan yang tidak perlu dibuang. Tahap penarikan dan verifikasi kesimpulan adalah tahap interpretasi data penelitian untuk ditarik kesimpulan berdasarkan fenomena yang didapatkan (Miles, M. B., \& Huberman, M.,2014).

\section{HASIL DAN PEMBAHASAN}

Dari hasil wawancara dengan guru diketahui bahwa guru telah melaksanakan PJJ dengan menggunakan platform google classroom, menggunakan media sosial instagram untuk mengumpulkan tugas membuat poster kampanye tentang bahaya virus dalam kehidupan manusia. Guru menggunakan aplikasi chatting yaitu whatsapp dan telegram sehingga guru dapat memberikan informasi tentang hal-hal yang berkaitan dengan mata pelajaran. Siswa juga dapat mengirim pesan pribadi melalui telegram atau whatsapp.

Melalui angket yang diberikan kepada siswa, diperoleh hasil sebagai berikut:

\section{Siswa melaksanakan PJJ}

Dari hasil angket yang diberikan diketahui bahwa semua (100\%) siswa kelas X SMA Negeri 2 Medan melaksanakan Pembelajaran Jarak Jauh (PJJ) dari rumah. Siswa melaksanakan PJJ setiap hari (100\%) sesuai dengan jadwal PJJ dari SMA Negeri 2 Medan dengan rata-rata waktu dalam satu hari 3-4 jam (20\%), 5-6 jam (70\%), dan lebih dari 6 jam (10\%).

Pelaksanaan PJJ oleh SMA Negeri 2 Medan diselenggarakan setiap hari senin 
hingga sabtu dari jam 07.15 - 12.00. Setiap guru mata pelajaran memberikan materi pembelajaran sesuai dengan jadwal yang ditentukan. Untuk memantau kehadiran siswa dalam melaksanakan pembelajaran, maka guru memberikan daftar hadir online. Melalui daftar hadir online tersebut dapat diketahui apakah siswa hadir atau tidak dalam pembelajaran yang sedang berlangsung.

\section{Pelaksanaan PJJ siswa}

Pada angket ini, siswa diperbolehkan memilih lebih dari satu jawaban angket. Dari hasil angket yang diberikan diketahui bahwa siswa mengerjakan soal-soal dari guru $(100 \%)$, belajar dari buku teks pelajaran (100\%), belajar interaktif bersama guru sekolah secara online (daring) (100\%), belajar dari aplikasi belajar daring (online) $(50 \%)$, belajar menggunakan berbagai sumber belajar digital $(100 \%)$.

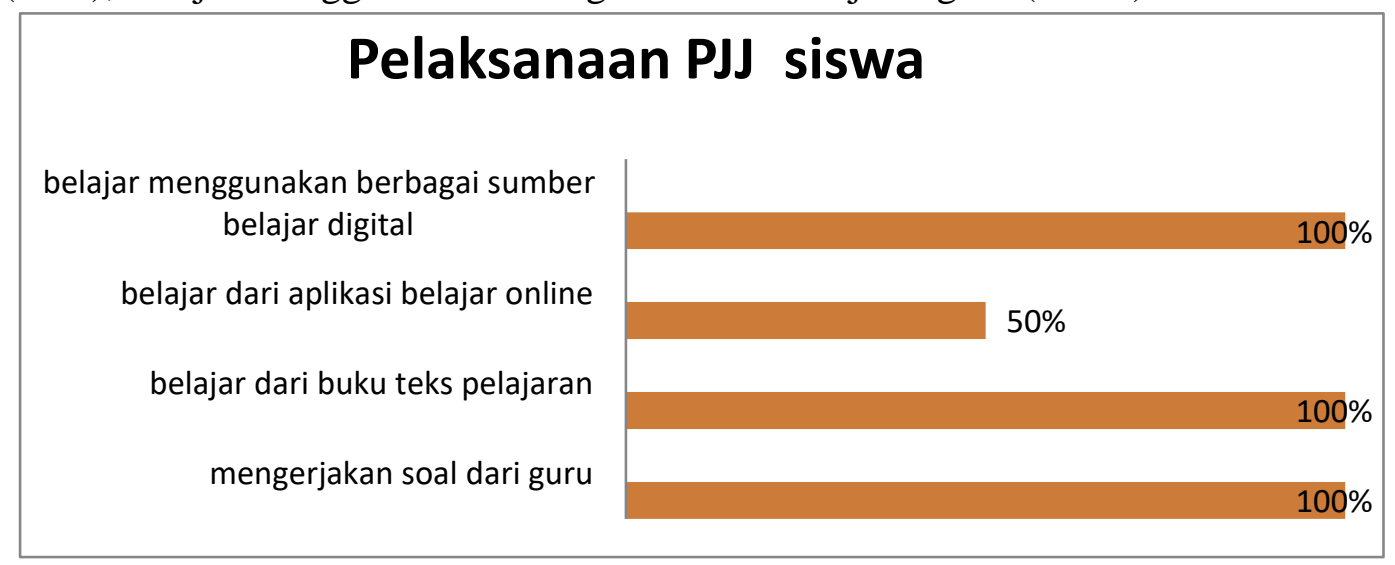

\section{Fasilitas yang dimiliki siswa selama PJJ}

Pada angket ini, siswa diperbolehkan memilih lebih dari satu jawaban angket. Dari hasil angket yang diberikan diketahui bahwa siswa memiliki fasilitas yang mendukung PJJ dari rumah yaitu listrik (100\%), internet (100\%), komputer/laptop/tablet (40\%), telepon pintar (smartphone) (90\%). Siswa yang tidak memiliki telepon pintar (smartphone) sendiri sebanyak $10 \%$ biasanya meminjam milik orangtuanya untuk dapat melaksanakan PJJ.

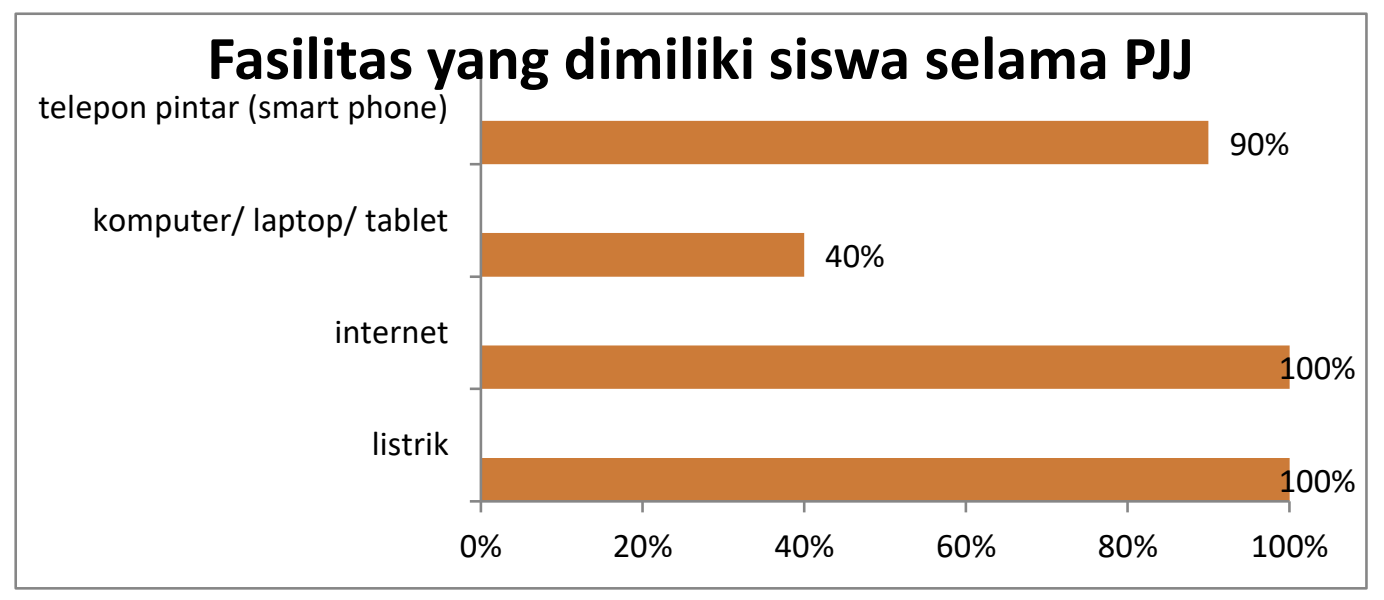

\section{Berinteraksi dengan guru dalam pembelajaran selama PJJ}

Dari hasil angket yang diberikan diketahui bahwa siswa melakukan interaksi melalui kelas online yang disediakan guru yaitu Google Classroom (100\%), melakukan interaksi melalui media sosial (instagram) (100\%), melakukan interaksi melalui video conference yang disediakan guru (zoom cloud meeting) (100\%), melakukan interaksi melalui grup chat (telegram, whatsapp) (100\%).

Aplikasi utama yang digunakan oleh guru Biologi kelas X SMA Negeri 2 Medan dalam menyelenggarakan PJJ adalah google classroom. Melalui media tersebut 
guru memberikan daftar hadir, materi dan tugas-tugas kepada siswa. Instagram juga digunakan saat mengumpulkan tugas membuat poster kampanye tentang bahaya virus dalam kehidupan manusia. Untuk dapat berinteraksi melalui video conference, guru biologi melaksanakan zoom cloud meeting bersama siswa kelas $\mathrm{X}$ agar dapat memaparkan materi pokok yang sedang dipelajari dan dapat berdiskusi pada saat bersamaan. Untuk mempermudah dalam memberikan informasi terkait pelajaran, maka guru biologi dan siswa melaksanakan interaksi melalui grup chat di telegram dan whatsapp. Pesan pribadi siswa kepada guru juga dilaksanakan melalui media telegram dan whatsapp untuk mempermudah guru maupun siswa dalam berkomunikasi terkait pelajaran biologi.

\section{Aplikasi belajar daring yang digunakan selama PJJ}

Pada angket ini, siswa diperbolehkan memilih lebih dari satu jawaban angket. Dari hasil angket yang diberikan diketahui bahwa aplikasi daring yang digunakan oleh siswa selama PJJ adalah google classroom (100\%). Aplikasi utama yang digunakan dalam PJJ Biologi kelas X SMA Negeri 2 Medan adalah google classroom, namun untuk lebih memahami pelajaran Biologi dengan lebih baik, siswa juga menelurusi aplikasi ruang guru (50\%), rumah belajar (35\%) dan aplikasi belajar lainnya (10\%). Kehadiran aplikasi pendidikan dalam PJJ ini sangat membantu para siswa untuk dapat mengatasi kesulitan dalam memahami pelajaran.

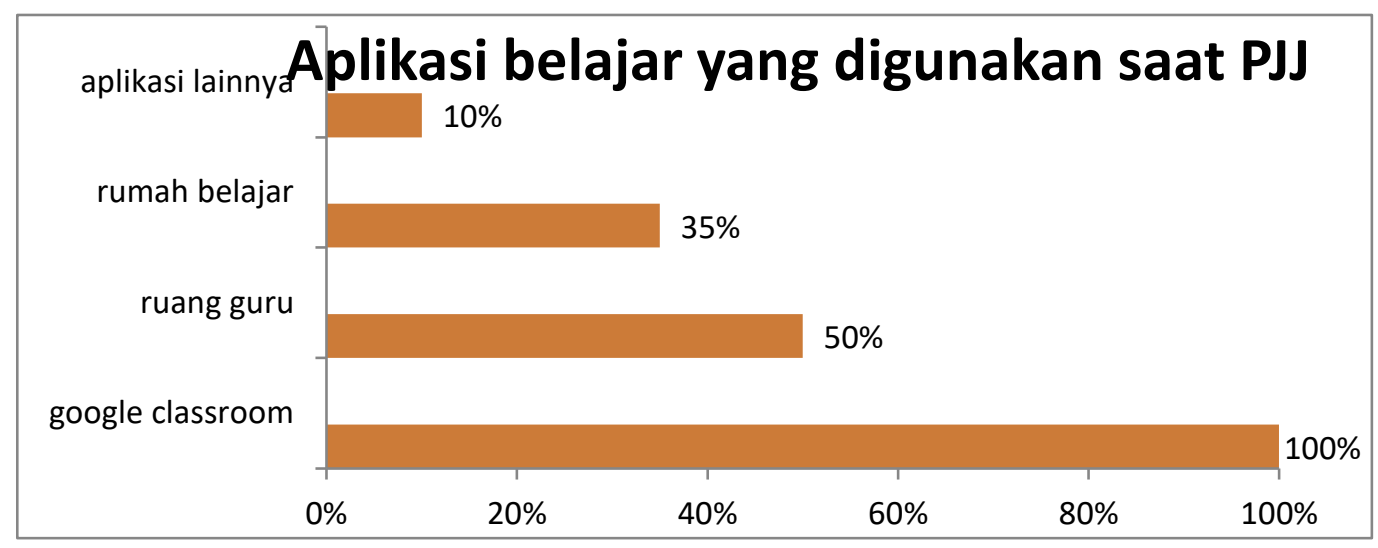

\section{Hambatan yang dialami saat PJJ}

Pada angket ini, siswa diperbolehkan memilih lebih dari satu jawaban angket. Dari hasil angket yang diberikan diketahui bahwa hambatan yang dialami oleh siswa saat PJJ dari rumah antara lain kurang konsentrasi (50\%), kesulitan memahami pelajaran (32\%), tidak dapat bertanya langsung kepada guru (67 \%), tidak dapat bertanya langsung kepada teman-teman (40\%), bosan (85\%).

Hal-hal tersebut terjadi karena siswa tidak dapat bertemu langsung dengan teman-teman sekelasnya dan juga guru. Ketika saat pembelajaran di sekolah, jika ada materi yang kurang dipahami siswa dapat langsung bertanya kepada guru maupun teman sekelas. Namun saat PJJ siswa mengalami kesulitan sehingga menjadi kurang konsentrasi dan bahkan bosan.

\section{Dukungan yang diberikan sekolah selama PJJ}

Dari hasil angket yang diberikan diketahui bahwa pihak sekolah memberikan dukungan selama PJJ antara lain meminjamkan buku (100\%), memberi paket data internet (100\%).

Peminjaman buku perpustakaan yang diselenggarakan oleh pihak sekolah sangat membantu siswa agar dapat membaca materi pelajaran yang sedang dipelajari. Pemberian paket data internet kepada guru dan siswa yang diselenggarakan oleh pemerintah juga sangat membantu karena ketersediaan data internet merupakan hal yang paling utama agar PJJ dapat berlangsung dengan baik. Kesulitan ekonomi akibat 
Covid-19 yang dialami oleh para orang tua siswa, dapat terbantu dengan pemberian paket data internet tersebut.

\section{Kesan selama melaksanakan PJJ}

Pada angket ini, siswa diperbolehkan memilih lebih dari satu jawaban angket. Dari hasil angket yang diberikan diketahui bahwa siswa berpendapat masih bisa memahami materi pembelajaran selama PJJ dari rumah $(90 \%)$, merasa belajar dari rumah itu menyenangkan (55\%), mendapat bimbingan dari orangtua atau keluarga selama PJJ dari rumah (35\%), mudah mendapatkan sumber belajar selama PJJ dari rumah (100\%), dan tetap bisa berkonsentrasi saat belajar dari rumah (100\%).

Berdasarkan hasil pengamatan PJJ melalui zoom cloud meeting, diperoleh hasil bahwa siswa aktif dalam pembelajaran yang dilaksanakan. Setelah guru memberikan materi pelajaran, guru menyediakan waktu untuk diskusi. Pada diskusi tersebut, siswa terlihat aktif dalam mengajukan beberapa pertanyaan yang terkait dengan materi pelajaran.

Ketersediaan internet di rumah merupakan kunci kesuksesan PJJ di rumah. Jika mengalami kesulitan dalam memahami materi pelajaran, siswa dapat menelusuri melalui mesin pencari ataupun mengunjungi situs website pelajaran yang tersedia.

\section{PENUTUP}

Berdasarkan hasil penelitian dan pembahasan yang telah dikemukakan maka dapat disimpulkan bahwa Guru dan siswa Kelas X SMA Negeri 2 Medan TP. 2020/2021 telah melaksanakan Pembelajaran Jarak Jauh (PJJ). Siswa melaksanakan PJJ setiap hari, rata-rata 5-6 jam per hari. Dalam pelaksanaan PJJ, siswa mengikuti kelas online yang disediakan guru yaitu Google Classroom, berinteraksi melalui video conference (zoom cloud meeting), instagram, grup chat (telegram, whatsapp), juga melalui aplikasi belajar online lainnya. Siswa berpendapat masih bisa memahami materi pembelajaran, menyenangkan, mudah mendapatkan sumber belajar, dan tetap bisa berkonsentrasi. Namun sebagian siswa mengeluh tidak dapat bertanya langsung kepada guru atau teman-teman, dan bosan.

\section{DAFTAR PUSTAKA}

Ariadhy, Shulby Y. 2020. Pelatihan Pembelajaran Jarak Jauh di Era Pandemi Covid-19. Jurnal Pengabdian Masyarakat ANOA. Vol 1 No. 3 Hal 220-226 Agustus 2020.

Arikunto, S. 2013. Prosedur Penelitian Suatu Pendekatan Praktik. Edisi Revisi. Jakarta: PT. Rineka Cipta.

cnnIndonesia. 2020. https://www.cnnindonesia.com/nasional/20201110123516-25568018/kilas-balik-pandemi-covid-19-di-indonesia

detiknews.com. 2020. https://news.detik.com/berita/d-4966701/asal-usul-virus-coronaberasal-dari-mana-sebenarnya

Kemdikbud. 2020. https://www.kemdikbud.go.id/main/blog/2020/03/mendikbudterbitkan-se-tentang-pelaksanaan-pendidikan-dalam-masa-darurat-covid19

Miles, M.B, Huberman, A.M, \& Saldana, J. (2014). Qualitative Data Analysis, A Methods Sourcebook, Edition 3. USA: Sage Publications. Terjemahan Tjetjep Rohindi Rohidi, UI-Press.

Muhammadiyah, U., \& Utara, S. (2020). JURNAL ILMIAH AQUINAS p-ISSN: 26157683 e-ISSN: 2714-6472. Jurnal Ilmiah Aquinas, 3(2), 306-315.

Rigianti, Henry Aditia (2020). Kendala Pembelajaran Daring Guru Sekolah Dasar Di Kabupaten Banjarnegara, Elementary School, Vol.7, No.2 Halaman 297-302

Sadikin, Ali. 2020. Pembelajaran Daring di Tengah Wabah Covid-19 BIODIK: Jurnal Ilmiah Pendidikan Biologi ISSN 2580-0922 (online), ISSN 2460-2612 (print) Volume 6, Nomor 02, Tahun 2020, Hal. 214-224 
Siagian, Tiodora Hadumaon (2020). Mencari Kelompok Berisiko Tinggi Terinfeksi Virus Corona Dengan Discourse Network Analysis, Jurnal Kebijakan Kesehatan Indonesia: JKKI, Vol. 09, No. 02 Juni 2020 Halaman 98-106

Sugiyono, 2011. Metode Penelitian Kuantitatif, Kualitatif dan R\&D. Bandung: Alfabeta.

Unicef (2020). COVID-19 Dan Anak-Anak Di Indonesia Agenda Tindakan Untuk Mengatasi Tantangan Sosial Ekonomi 11 May 2020. Diunduh 1 Nopember 2020 dari Https://Www.Unicef.Org/Indonesia/Sites/Unicef.Org.Indonesia/Files/2020-05/COVID-19Dan-Anak-Anak-Di-Indonesia-2020_1.Pdf 